\title{
Optimization of Thermal Deformation in Probe Card
}

\author{
Yong-Hoon Chang ${ }^{1}$, Jeong-Je Yin ${ }^{2^{*}}$ and Yong S. Suh ${ }^{3}$ \\ ${ }^{1}$ Department of Mechanical and Automotive Engineering, Induk University \\ ${ }^{2}$ Department of Mechanical Engineering Design, Induk University \\ ${ }^{3}$ Department of Mechanical Engineering, California State University, Sacramento, USA \\ 프로브 카드의 열변형 최적화 \\ 장용훈 ${ }^{1}$, 인정제 ${ }^{2 *}$, Yong S. Suh ${ }^{3}$ \\ ${ }^{1}$ 인덕대학 기계자동차과, ${ }^{2}$ 인덕대학 기계설계과, ${ }^{3} \mathrm{CSU}$ Sacramento 기계공학과
}

\begin{abstract}
A probe card is used in testing semiconductor wafers. It must maintain a precise location tolerance for a fine pitch due to highly densified chips. However, high heat transferred from its lower chuck causes thermal deformations of the probe card. Vertical deformation due to the heat will bring contact problems to the pins in the probe card, while horizontal deformation will cause positional inaccuracies. Therefore, probe cards must be designed with proper materials and structures so that the thermal deformations are within allowable tolerances. In this paper, heat transfer analyses under realistic loading conditions are simulated using ANSYS $^{\mathrm{TM}}$ finite element analysis program. Thermal deformations are calculated based on steady-state temperature gradients, and an optimal structure of the probe card is proposed by adjusting a set of relevant design parameters so that the deformations are minimized.

요 약 프로브 카드는 웨이퍼의 칩 검사에 사용된다. 또한 반도체의 고집적화에 따른 미세피치 대응으로 높은 위치 정도가 요구된다. 그러나 실제 장비에서는 하부 척에서 높은 열이 프로브 카드로 전달되어, 프로브 카드의 열변형을 초래하게 된다. 프로브 카드의 수직방향 열변형은 핀의 접촉관련 문제를 야기할 것이고, 수평방향의 열변형은 $\mathrm{x}-\mathrm{y}$ 방 향으로의 위치 오차를 만들 것이다. 따라서 프로브 카드는 허용 범위내의 열변형이 이루어지도록 재질과 구조를 갖게 설계되어야 한다. 본 연구에서는 유한요소 해석프로그램인 $\mathrm{ANSYS}^{\mathrm{TM}}$ 를 이용하여 프로브 카드의 실제 부하 조건들을 적용한 열전달 해석을 수행하였다. 정상상태 온도 구배에 대해 열변형이 계산되었으며, 최종적으로 적절한 설계변수 들을 조정하여 열변형이 최소화 될 수 있는 새로운 구조를 제안하였다.
\end{abstract}

Key Words : Thermal Deformation, FEM, Probe Card

\section{Introduction}

A probe card is an interface between a semiconductor wafer and testing equipment that checks the electronic characteristics of the semiconductor chips during the manufacturing process. A series of parallel pins on the printed circuit board (PCB) in the probe card makes physical contacts with the IC output pads, and it transfers the internal electronic characteristics to the external testing equipment. A control system detects and removes any defect chips based on the signal characteristics it receives from the probe card. This reduces assembly and inspection time and improves the product yield rates.

Probe cards can be classified into different types based on the shapes of the contact elements. A vertical card[1,2] has tungsten wires sharpened to needles and assembled vertically, while a horizontal card has its wires bent and assembled horizontally. A MEMS card[3-5] is a vertical

*Corresponding Author : Jeong-Je Yin(jjyin@induk.ac.kr) 
type made using the semiconductor process technology. Higher density of integrated circuits reduces the I/O pad pitch of the chips, limiting the space for the probe cards. Hence, the horizontal type is replaced by the vertical type, and then further developed to MEMS vertical type.

In designing a probe card, its positional accuracy is getting more important because the pad pitch is smaller while the wafer size is getting larger. The heat transferred from the chuck under the probe card, however, develops horizontal and vertical deviations of the probe pins during the testing process. The vertical deviation causes contact errors of the pins, and the positional accuracy of the pins is affected by the horizontal deviation. Therefore, a proper structural design and choice of materials are important so that the deviations can be controlled and limited.

Related research experimentally shows that the thermal deformations affect the accuracy of the probe cards[6]. Others studied on the relationships between the heat distributions of the chuck and the thermal deformations of the probe cards $[7,8]$, and on the thermal deformations due to the layered structure of the printed wiring board (PWB)[9]. However, little research is found on the design of probe cards based on the analyses of their thermal deformations.

In this research, temperature distributions of a probe card under a realistic testing environment are investigated using a commercial finite element analysis package, ANSYS $^{\mathrm{TM}}$. Based on the thermal deformations through the analyses of temperature distributions, an optimal structure of a probe card that minimizes the thermal deformations is proposed. Also, this paper reports useful data for correcting the thermal deformations by analyzing the deformations of the probe cards under the loads applied to the pins in addition to the thermal deformations.

\section{Modeling of a Probe Card}

A probe card is an assembly of many components as shown in Fig. 1.

A test is performed after the bottom of the probe card is in contact with the lower chuck at $125{ }^{\circ} \mathrm{C}$ with a gap of $200 \mu \mathrm{m}$ for five minutes as shown in Fig. 2.

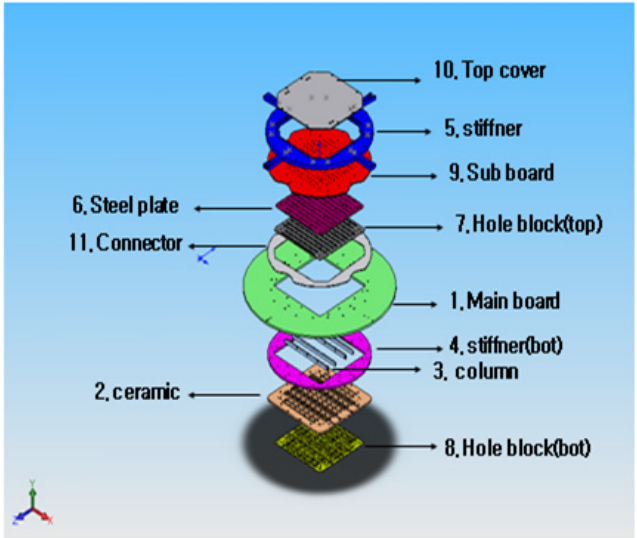

[Fig. 1] Exploded view of a probe card

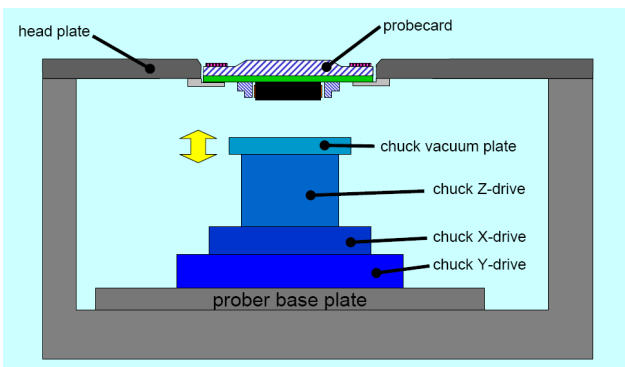

[Fig. 2] Schematic diagram for probe card test[10]

Table 1 illustrates the mechanical and thermal properties of the components in the probe cards used in the analysis of the paper. Anisotropic property of the PCB is considered.

[Table 1] Material properties of probe card parts

\begin{tabular}{|c|c|c|c|c|c|}
\hline Part & Material & $\begin{array}{c}\text { Young's } \\
\text { modulus } \\
\text { E (GPa) }\end{array}$ & $\begin{array}{c}\text { Conductance } \\
\left(\mathrm{W} / \mathrm{m}^{* K}\right)\end{array}$ & $\begin{array}{c}\text { Heat } \\
\text { capacity } \\
\left(\mathrm{J} / \mathrm{kg}^{*} \mathrm{~K}\right)\end{array}$ & $\begin{array}{c}\mathrm{CTE} \\
\left(\mathrm{K}^{-1}\right)\end{array}$ \\
\hline Ceramic & $\mathrm{AL}_{2} \mathrm{O}_{3}$ & 167 & 88.5 & 831 & $13.2 \times 10^{-6}$ \\
\hline Column & $\mathrm{A} 6061$ & 68.9 & 154 & 896 & $23.6 \times 10^{-6}$ \\
\hline $\begin{array}{c}\text { Steel } \\
\text { plate }\end{array}$ & $\mathrm{SUS303}$ & 193 & 16.2 & 500 & $17.2 \times 10^{-6}$ \\
\hline Stiffener & $\mathrm{S} 45 \mathrm{C}$ & 205 & 49.8 & 486 & $11.5 \times 10^{-6}$ \\
\hline PCB & FR4 & $\begin{array}{c}\mathrm{x}, \mathrm{y} 16.9 \\
\mathrm{z} 7.44\end{array}$ & 0.291 & 1,200 & $\begin{array}{c}\mathrm{x}, \mathrm{y} \\
16.0 \times 10^{-6} \\
\mathrm{z}\end{array}$ \\
\hline $\begin{array}{c}\text { Hole } \\
\text { block }\end{array}$ & $\begin{array}{c}\text { POLYI } \\
\text { MIDE }\end{array}$ & 4 & 0.35 & 1,200 & $54.0 \times 10^{-6}$ \\
\hline- & Air & - & 0.026 & 1,010 & - \\
\hline
\end{tabular}

Fig. 3 shows the meshed probe card model for finite element analyses. The empty space inside the probe card 
is also meshed in order to analyze the heat transfer through the air. The air mesh is then removed in the deformation analysis that follows the heat distribution analysis.

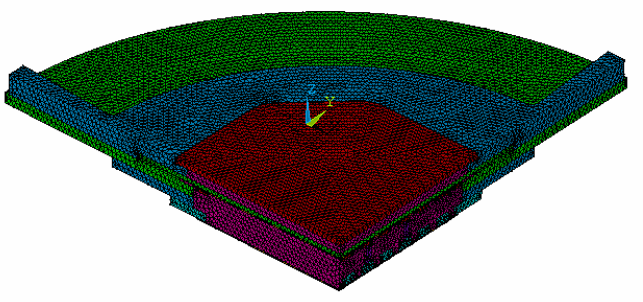

[Fig. 3] Mesh model of the probe card for the finite element analysis

\section{Heat Transfer Analysis}

Fig. 3 shows a finite element model using 10 node tetra solid elements for a heat transfer analysis. Thermal contact resistances among components are ignored. The empty space inside the probe card is also meshed using the same element type to analyze the heat transfer through the air. Heat convection to the environment is also considered assuming that the room temperature is at 25 ${ }^{\circ} \mathrm{C}$.

Under the above conditions, a transient heat transfer analysis is performed after five minutes have passed. The result is shown in Fig. 4 shows the steady state of heat transfer analysis for a comparison. In the figures, the top cover is removed to reveal and show the internal temperature distributions. The figures show that the temperature of the external surface of the probe card is close to the room temperature while the temperature gradient at the center is steep. Comparing the two temperature distributions in Fig. 4, it can be shown that the temperature reaches close to the steady state after five minutes.

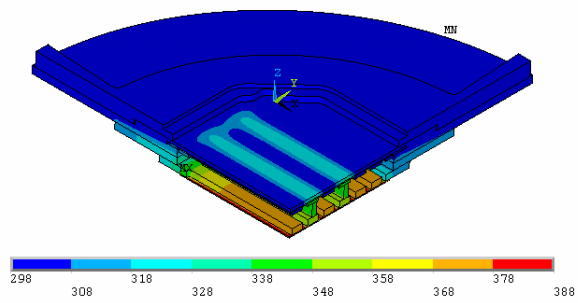

(a) after 5 minutes

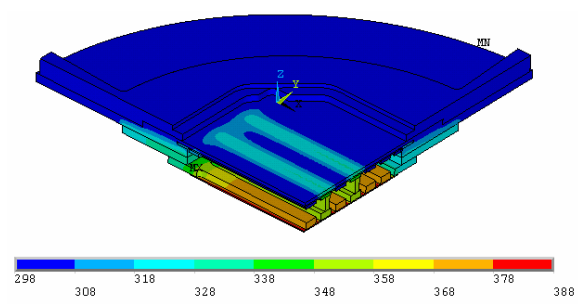

(b) steady state

[Fig. 4] Comparison of temperature distributions

\section{Analysis of Thermal Deformations}

A thermal deformation analysis is performed after removing the air mesh in the empty space in the probe card. The results show that the maximum deviations are within $50 \mu \mathrm{m}$ and $10 \mu \mathrm{m}$ in the $\mathrm{X}$ and $\mathrm{Y}$ directions respectively, which are considered to be within allowable deviations. The probe card deflects convex downward in the $\mathrm{Z}$ direction at the center as shown in Fig. 5. The maximum deviation is measured to be $160 \mu \mathrm{m}$.

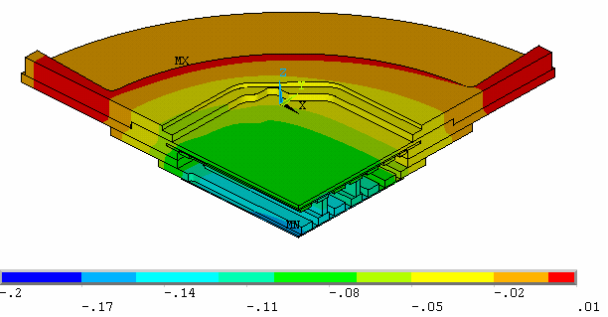

[Fig. 5] Z-displacements of the probe card due to thermal load

Fig. 5 shows the distributions of the thermal deformations in the Z-direction for the whole probe card. As the deformation of the sub-board to which the probe pins are attached is more important, Fig. 6 shows the 
Z-displacements of the sub-board due to heat. The sub-board also deflects convex downward with the maximum deformation of $103 \mu \mathrm{m}$.

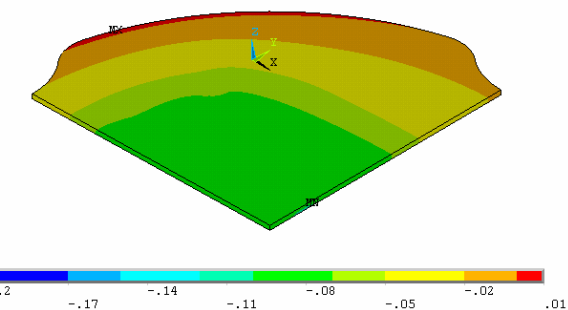

[Fig. 6] Z-displacements of the sub-board due to thermal load

\section{Optimization of Thermal Deformation}

To minimize the deformations due to heat in the $\mathrm{Z}$ direction, heat transfer and thermal deformation analyses are performed on five alternative structural designs by modifying the number of columns and their sizes as summarized in Table 2. Fig. 7 illustrates the five alternatives comparing with the initial model. Fig. 8 shows the Z-displacements of the alternative probe cards after running thermal analyses.
[Table 2] Design alternatives for the reduction of thermal deformation

\begin{tabular}{|c|c|c|c|c|}
\hline Case & $\begin{array}{c}\text { No. of } \\
\text { column }\end{array}$ & $\begin{array}{c}\text { Column } \\
\text { thickness } \\
(\mathrm{mm})\end{array}$ & $\begin{array}{c}\text { Column } \\
\text { length } \\
(\mathrm{mm})\end{array}$ & $\begin{array}{c}\text { Stiffener } \\
\text { thickness } \\
(\mathrm{mm})\end{array}$ \\
\hline Base model & 4 & 4 & 88 & 12 \\
\hline Model 1 & 6 & 4 & 88 & 12 \\
\hline Model 2 & 8 & 4 & 88 & 12 \\
\hline Model 3 & 8 & 6 & 88 & 12 \\
\hline Model 4 & 8 & 6 & 91 & 12 \\
\hline Model 5 & 8 & 6 & 91 & 15 \\
\hline
\end{tabular}

Fig. 9 shows the Z-displacements of the sub-boards of which the deformations are considered to be the same as those of the probe pins. In the figure, the thermal displacements are reduced as the number of columns increases as summarized in Table 3.

[Table 3] Summary of thermal deformations

\begin{tabular}{|c|c|c|c|c|c|}
\hline Case & $\begin{array}{c}\text { Total } \\
\text { weight } \\
(\mathrm{kg})\end{array}$ & $\begin{array}{c}\text { Weight } \\
\text { change } \\
(\mathrm{kg})\end{array}$ & $\begin{array}{c}\text { Weight } \\
\text { increase } \\
(\%)\end{array}$ & $\begin{array}{c}\text { Max. } \\
\text { Z-disp. } \\
(\mu \mathrm{m})\end{array}$ & $\begin{array}{c}\text { Deformati } \\
\text { on } \\
\text { reduction } \\
\text { rate }(\%)\end{array}$ \\
\hline Base model & 7.78 & 0.00 & 0.0 & -103 & 0 \\
\hline Model 1 & 7.82 & 0.04 & 0.5 & -87 & 16 \\
\hline Model 2 & 7.86 & 0.08 & 1.0 & -66 & 36 \\
\hline Model 3 & 7.94 & 0.16 & 2.1 & -64 & 38 \\
\hline Model 4 & 7.95 & 0.17 & 2.2 & -61 & 41 \\
\hline Model 5 & 8.96 & 1.17 & 15.1 & -52 & 50 \\
\hline
\end{tabular}

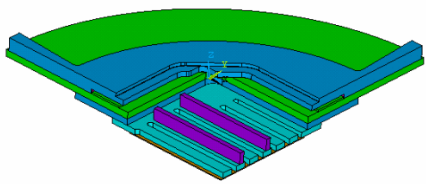

(a)

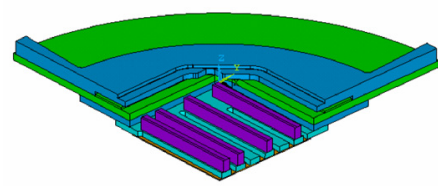

(d)

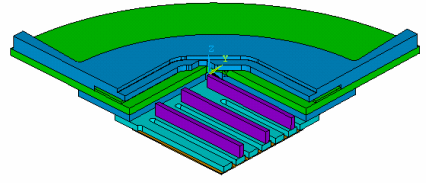

(b)

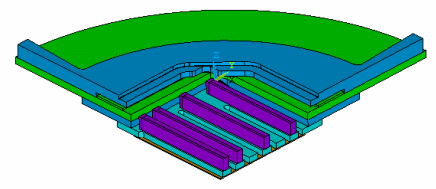

(e)

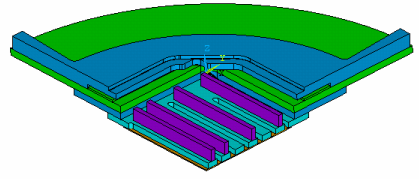

(c)

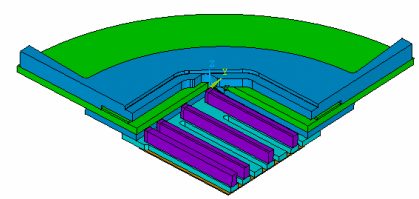

(f)

[Fig. 7] Modification of internal structure for the reduction of thermal deformation (a) initial model, (b) add 2 columns, (c) add 4 columns, (d) add 4 columns, increase thickness $2 \mathrm{~mm}$, (e) add 4 columns, increase thickness $2 \mathrm{~mm}$, increase length $3 \mathrm{~mm}$, (f) add 4 columns, increase thickness $2 \mathrm{~mm}$, increase length $3 \mathrm{~mm}$, increase stiffener thickness $3 \mathrm{~mm}$ 

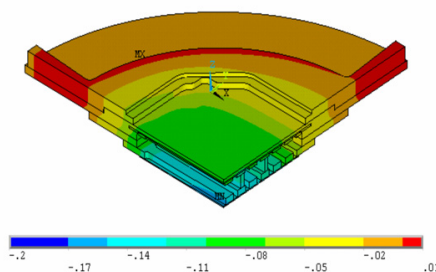

(a) base model

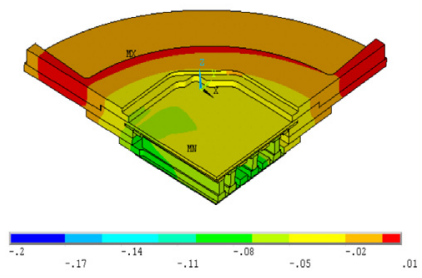

(d) model 3

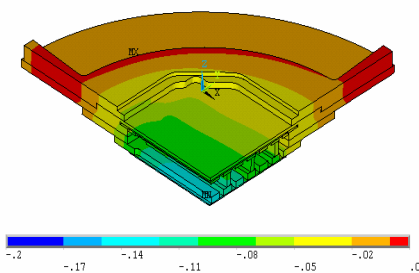

(b) model 1

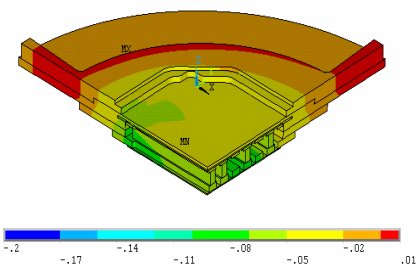

(e) model 4

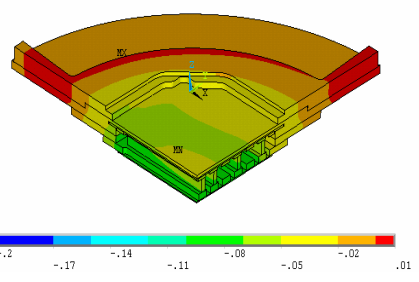

(c) model 2

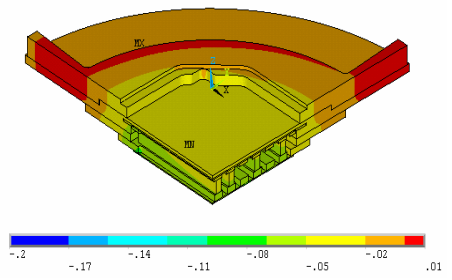

(f) model 5

[Fig. 8] Z-displacements of the alternative models (top view)

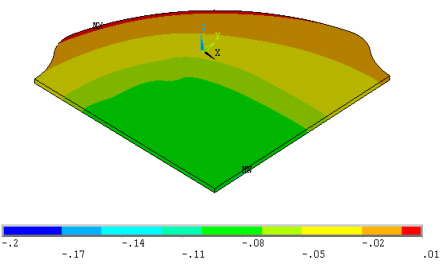

(a) base model

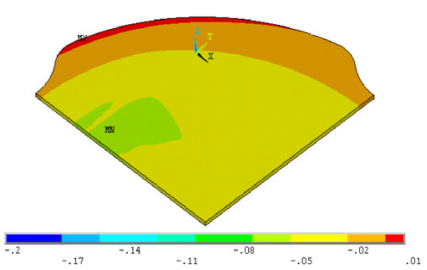

(d) model 3

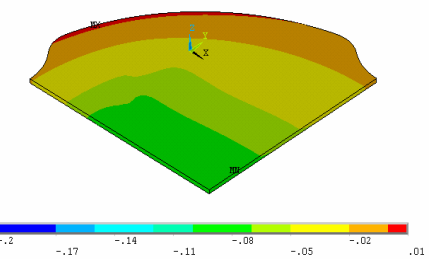

(b) model 1

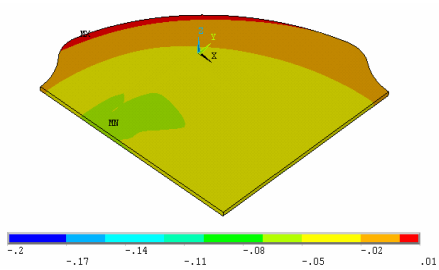

(e) model 4

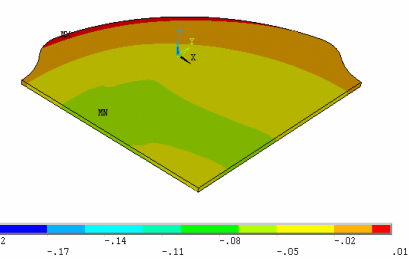

(c) model 2

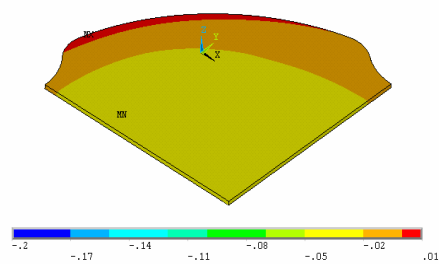

(f) model 5

[Fig. 9] Z-displacements of sub-boards for the alternative models 
Considering only the thermal displacements, the Model 5 gives the most reduction of Z-displacements by $50 \%$ from the base model. The increase of the thickness of the stiffeners, however, increases the weight to $1.17 \mathrm{~kg}$. The Model 4 gives a reduction rate of $41 \%$ in the displacement, but the weight increases only by $0.17 \mathrm{~kg}$, which is considered to be a better alternative.

Table 4 summarizes the Z-displacements at two points as shown in Fig. 10, and this data can be used in designing the probe card compensating the thermal deformations.

[Table 4] Z-displacements at specific points

\begin{tabular}{|c|c|c|c|}
\hline \multirow{2}{*}{ Case } & \multicolumn{2}{|c|}{ Z-disp. ( $\mu \mathrm{m})$} & \multirow{2}{*}{$\begin{array}{c}\mathrm{dZ}_{\mathrm{C}^{-}-\mathrm{d} \mathrm{Z}_{\mathrm{O}}} \\
(\mu \mathrm{m})\end{array}$} \\
\hline & $\mathrm{O}$ & $\mathrm{C}$ & \\
\hline Base model & -103 & 4 & 107 \\
\hline Model 1 & -87 & 3 & 90 \\
\hline Model 2 & -66 & 4 & 70 \\
\hline Model 3 & -64 & 4 & 68 \\
\hline Model 4 & -61 & 4 & 65 \\
\hline Model 5 & -52 & 4 & 56 \\
\hline
\end{tabular}

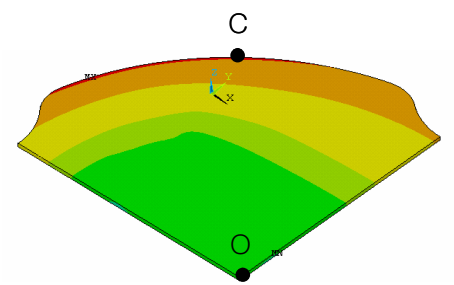

[Fig. 10] Locations of Z-displacement measurements

\section{Deformation Analysis Including Pin Loads}

Under the real operating condition of a probe card, an over-drive load is applied to the probe pins in the vertical ( $Z$ ) direction. The deformation due to the load is in the direction opposite to the thermal deformation. Hence, it will cancel out the thermal displacements discussed in the previous sections. In this paper, deformation analyses of a pin under the load are performed to calculate the amounts of vertical loads corresponding to certain vertical deflections of the pin. Based on the analyses, the total load to all the pins in a probe card is calculated assuming there are 10,000 pins per probe card. Assuming a uniform pressure distribution to the array of pins on the sub-board, deformation analysis due to the pressure is added after the thermal analysis to study the canceling effect in the Z-displacements. The results are summarized in Table 5, showing that the canceling effect due to the load is not significant comparing with the thermal deformations. Only $7 \mu \mathrm{m}$ of reduction is observed when the vertical displacement of a probe pin reaches $100 \mu \mathrm{m}$.

[Table 5] Z-displacement reduction of sub-board with pin load

\begin{tabular}{|c|c|c|c|c|c|}
\hline \multirow{2}{*}{$\begin{array}{c}\text { Normal pin } \\
\text { displaceme } \\
\mathrm{nt} \\
(\mu \mathrm{m})\end{array}$} & \multirow{2}{*}{$\begin{array}{c}\text { Pin } \\
\text { load } \\
(\mathrm{g})\end{array}$} & \multicolumn{2}{|c|}{$\begin{array}{c}\text { Z-disp. } \\
(\mu \mathrm{m})\end{array}$} & \multirow{2}{*}{$\begin{array}{c}\mathrm{dZ}_{\mathrm{C}^{-}} \\
\mathrm{dZ}_{\mathrm{O}} \\
(\mu\end{array}$} & $\begin{array}{c}\text { Reduction } \\
\text { of Z-disp. } \\
(\mu \mathrm{m})\end{array}$ \\
\hline 0 & - & -103 & 4 & 107 & - \\
\hline 25 & 0.86 & -102 & 4 & 106 & 1 \\
\hline 50 & 1.73 & -101 & 2 & 103 & 4 \\
\hline 75 & 2.59 & -100 & 1 & 101 & 6 \\
\hline 100 & 3.46 & -99 & 1 & 100 & 7 \\
\hline
\end{tabular}

Using the distribution patterns of the Z-displacements including the loads, it will be possible to design probe cards that maintain uniform contacts of pins in the $\mathrm{Z}$ direction even after some thermal deformations if the center $(\mathrm{O})$ and the end $(\mathrm{C})$ of the board are properly adjusted by utilizing the data.

\section{Conclusions}

For designing an optimal structure to minimize thermal deformations of a probe card, various simulations such as heat transfer, thermal deformations, structural design alternatives, and deformation analysis due to pin loads are performed. The boundary conditions and the parameters for the analyses include thermal boundary conditions around the probe card, thickness of the stiffener, number of columns, and over-drive load conditions of pins. The conclusions of the analyses are as follows:

1. Heat transfer analyses give transient and steady state temperature distributions in terms of time. It is found that the temperature gradient is steep at the 
center where heat dissipation is relatively low.

2. A method to minimize the thermal deformation of a probe card using thermal deformation analyses is demonstrated. The vertical deflection of probe pins is an important indication of pin contacts and the stability of the card. A new design is proposed so that the vertical deflection is reduced by up to $50 \%$.

3. The number and the thickness of the columns are changed to minimize the thermal deformations. It can be shown that the thermal deformations are reduced significantly as the number of columns increases. An optimal design is found to use eight columns, each with $6 \mathrm{~mm}$ thickness, to minimize the weight and the deformations.

4. Assuming a uniform pressure is applied to the array of pins, deformation analyses due to the pressure are added to investigate their canceling effect on the Z-displacements of the probe pins due to the thermal deformations.

\section{References}

[1] C.H. Min and T.S. Kim, "Development and Characterization of Vertical Type Probe Card for High Density Probing Test", Journal of the Korean Institute of Electrical and Electronic Material Engineers, Vol. 19, No. 9, pp. 825-831, September 2006.

[2] J.T. Chiu, D.Y. Chang, "A new probe design combining finite element method and optimization used for vertical probe card in wafer probing", Precision Engineering, Volume 33, Issue 4, pp.395-401, 2009.

[3] C.H. Min and T.S. Kim, "Development of 121 pins $/ \mathrm{mm}^{\wedge} 2$ High Density Probe Card using Micro-spring Architecture", Journal of the Korean Institute of Electrical and Electronic Material Engineers, Vol. 20, No. 9, pp. 749-755, September 2007.

[4] H.J. Lee, J.Y. Kim, S.J. Lee, H.J. Choi, K.S. Kim and J.H. Kim, "Reliability Design of MEMS based on the Physics of Failures by Stress \& Surface Force", Proceedings of the KSME Conference, pp. 1730-1733, 2007.

[5] S. Ha, D. Kim, B. Shin, M. Cho and C. Han,
"Assessment of Design and Mechanical Characteristics of MEMS Probe Tip with Fine Pitch", Journal of the Korea Academia-Industrial cooperation Society, Vol. 11, No. 4, pp. 1210-1215, 2010.

[6] R. Schwartz, "Probe Card Metrology: High Temperature Testing of Probe Cards", IEEE Semiconductor Wafer Test Workshop, 2002.

[7] S.S Lee, J.Y. Yun and M.K. Kim, "Surface Thermal Deformation of 12 inch hot-cold chuck", Proceedings of the Korean Society Of Semiconductor Equipment Technology, pp. 207-211, 2003.

[8] Y. Joo, H. Shin and M.K. Kang, "A Study of Improvement of Low Temperature Uniformity of Wafer Prober Chuck", Journal of the Korea Academia-Industrial cooperation Society Vol. 10, No. 10, pp. 2572-2576, 2009.

[9] H.S. Lee, "Thermophysical Properties of PWB for Microelectronic Packages with Solder Resist Coating Process", Journal of the Microelectronics \& Packaging Society, Vol. 10, No. 3, pp. 73-82, 2003.

[10] Gunther Boehm, "Prober Stability with Large Probing Area and High Pin count", 2006 SWTW (South West Test Workshop)

Yong-Hoon Chang

[Regular member]

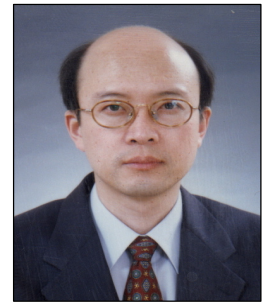

- Feb. 1988 : M.S. Department of Mechanical Engineering, Sungkyunkwan University

- Apr. 1997 : Ph.D. Department of Mechanical Engineering, University of Florida, USA

- May. $1997 \sim$ Aug. 1999 : Senior Researcher, Samsung Aerospace Industries, LTD.

- Aug. $1999 \sim$ Current : Associate Professor, Department of Mechanical and Automotive Engineering, Induk University 
Jeong-Je Yin

[Regular member]

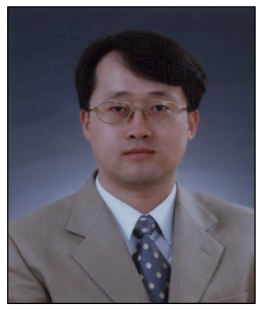

- Aug. 1992 : Ph.D. Department of Mechanical Design \& Production Engineering, Seoul National University

- Jan. $1993 \sim$ Apr. 1995 : Senior Researcher, Korea Automotive Technology Institute

- May. $1995 \sim$ Aug. 1999 : Principal Researcher, Institute for Advanced Engineering

- Aug. $1999 \sim$ Current : Associate Professor, Department of Mechanical Engineering Design, Induk University

Yong S. Suh

[Regular member]

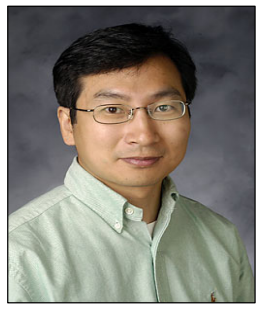

- Nov. 1995 : Ph.D. Department of Mechanical Engineering, Rensselaer Polytechnic Institute (RPI), USA

- Nov. $1995 \sim$ Jul. 1998 : Structural Dynamics Research Corporation (SDRC), USA

- Aug. 1998 - Nov 2003 : SolidWorks Corporation, USA

- Jan. $2004 \sim$ Current : Associate Professor, Department of Mechanical Engineering, California State University, Sacramento, USA 